TINJAUAN PUSTAKA

\title{
Anestesi Pada Mediastinoskopi
}

Satrio Adi Wicaksono ${ }^{*}$, Hari Hendriarto Satoto ${ }^{*}$, Heru Dwi Jatmiko

*Departemen Anestesiologi, Bagian/SMF Anestesiologi dan Terapi Intensif, Fakultas Kedokteran, Universitas Diponegoro/ RSUP Dr. Kariadi Semarang

\begin{abstract}
ABSTRACK
Mediastinoscopy is a thoracic surgical procedure performed with a mediastinoscope to examine the mediastinum which is the space in the thoracic cavity between the lungs for various indications. From anesthetic point of view, mediastinoscopy uses general anesthesia. Venous access with large diameter intravenous catheters (14 to 16 gauge) is required because of the risk of excessive bleeding and difficulty controlling bleeding. In this review we will explain the management of anesthesia in patients undergoing mediastinoscopy.
\end{abstract}

Keywords: mediastinoscopy, general anesthesia, management of anesthesia, mediastinum, bleeding

\begin{abstract}
ABSTRAK
Mediastinoscopy adalah prosedur bedah toraks yang dilakukan dengan mediastinoscope untuk memeriksa mediastinum yang merupakan ruang dalam rongga toraks antara paruparu untuk berbagai indikasi. Dari sudut pandang anestesi, mediastinoscopy menggunakan anestesi umum. Akses vena dengan kateter intravena berdiameter besar (ukuran 14 sampai 16) diperlukan karena risiko perdarahan yang berlebihan dan kesulitan mengendalikan perdarahan. Dalam ulasan ini kami akan menjelaskan manajemen anestesi pada pasien yang menjalani mediastinoscopy.
\end{abstract}

Kata Kunci: mediastinoscopy, anestesi umum, manajemen anestesi, mediastinum, perdarahan

\section{PENDAHULUAN}

Mediastinoskopi adalah prosedur dokumentasi, yang pertama kali dibahas oleh Carlens pada tahun 1959. Meskipun semakin canggih teknik pencitraan (misalnya emisi positron tomografi), mediastinoskopi tetap penting dalam pementasan kanker paru-paru dengan faktor-faktor yang terkait dengan tingginya sensitivitas $(0,80 \%)$ dan spesifisitasnya yang tinggi (100\%) ${ }^{1}$ indikasi lain untuk mediastinoskopi adalah biopsi massa mediastinum terutama di mana pemeriksaan lainnya, seperti CT kurang sensitif dan biopsi lebih tepat dan tepat untuk menegakkan diagnosis pada beberapa penyakit dengan limfadenopati mediastinum (misalnya sarkoidosis, limfoma).

Pada mediastinoskopi kita menggunakan anestesi umum, dimana relaksan otot 
harus dihindari pada pasien dengan sugestif sindrom klinis myasthenia gravis, dan Akses vena dengan kateter intravena diameter besar (14 hingga 16 gauge) diharuskan karena resiko perdarahan berlebihan dan kesulitan pengendalian perdarahan.

Diharapkan pada tinjauan ini, kita dapat mengerti apa mediastinoskopi dan bagaimana pengelolaan dan manajemen anestesi pada pasien-pasien yang akan dilakukan mediastinoskopi.

\section{ANATOMI}

Mediastinum yaitu rongga yang berada di antara paru kanan dan kiri. Mediastinum berisi jantung, pembuluh darah, pembuluh darah, trakea, pembuluh timus, syaraf, jaringan ikat, tabung getah bening dan salurannya. ${ }^{3,4}$

Rongga mediastinum ini terbatas dan tidak dapat difungsikan, maka pembesaran tumor dapat didukung organ di atas dan dapat menyebabkan kegawatan yang terkonsentrasi pada jiwa. Sebagian besar tumor mediastinum tumbuh semakin tinggi sehingga pasien sering datang pada tumor yang cukup besar

Secara garis besar mediastinum dibagi atas 4 bagian penting: ${ }^{4}$

1. Mediastinum superior, mulai pintu atas rongga dada sampai ke tulang belakang torakal ke-5 dan bagian bawah sternum, berisi: arkus aorta, arteri innominata dan bagian toraks dari carotis communis kiri dan arteri subklavia kiri; vena innominata dan setengah bagian atas vena kava superior; v. interkostalis kiri; nervus vagus, jantung, nervus frenikus, trakea, esofagus, ductus toraksicus, sisa-sisa timus, dan beberapa sisa getah bening.

2. Mediastinum anterior, dari garis batas mediastinum superior ke diafargma di depan jantung. berisi beberapa jaringan yang berbeda, beberapa kapal yang naik dari permukaan hati, dua atau tiga tingkat getah bening dari mediastinum anterior, dan cabang-cabang kecil dari arteri mammaria interna.

3. Mediastinum posterior, dari garis batas mediastinum superior ke diafragma di belakang jantung. berisi bagian dari aorta torakalis descenden, nena azigos dan dua vena hemiazygos, nervus vagus dan splanknikus, esofagus, saluran toraks, dan berbagai macam getah bening.

4. Mediastinum medial (tengah), dari garis batas mediastinum superior ke diafragma di antara mediastinum anterior dan posterior. Menampilkan jantung yang tertutup dalam perikardium, aorta asendens, bagian bawah dari vena kava superior dengan membuka vena azigos ke dalam, percabangan dari trakea dan dua bronkus, arteri pulmonalis yang terbagi menjadi dua cabang, vena pulmonalis kanan dan kiri, nervus frenikus, dan banyak getah bening.

Klasifikasi ini digunakan untuk menggambarkan asal dan menyebarkan tumor (yaitu anterior, dibahas dengan, atau di belakang jantung dan perikardium) dan harus dicatat bahwa tidak ada anatomis atau fasia menginstal kompartemen yang berbeda. Mediastinum kaya pada gilirannya getah bening yang merupakan tempat inflamasi lokal penyakit, limfatik utama tumor atau penyakit metastasis. Tabel 1 memberikan daftar kondisi yang dapat dilihat sebagai massa mediastinum ${ }^{3,4}$ 


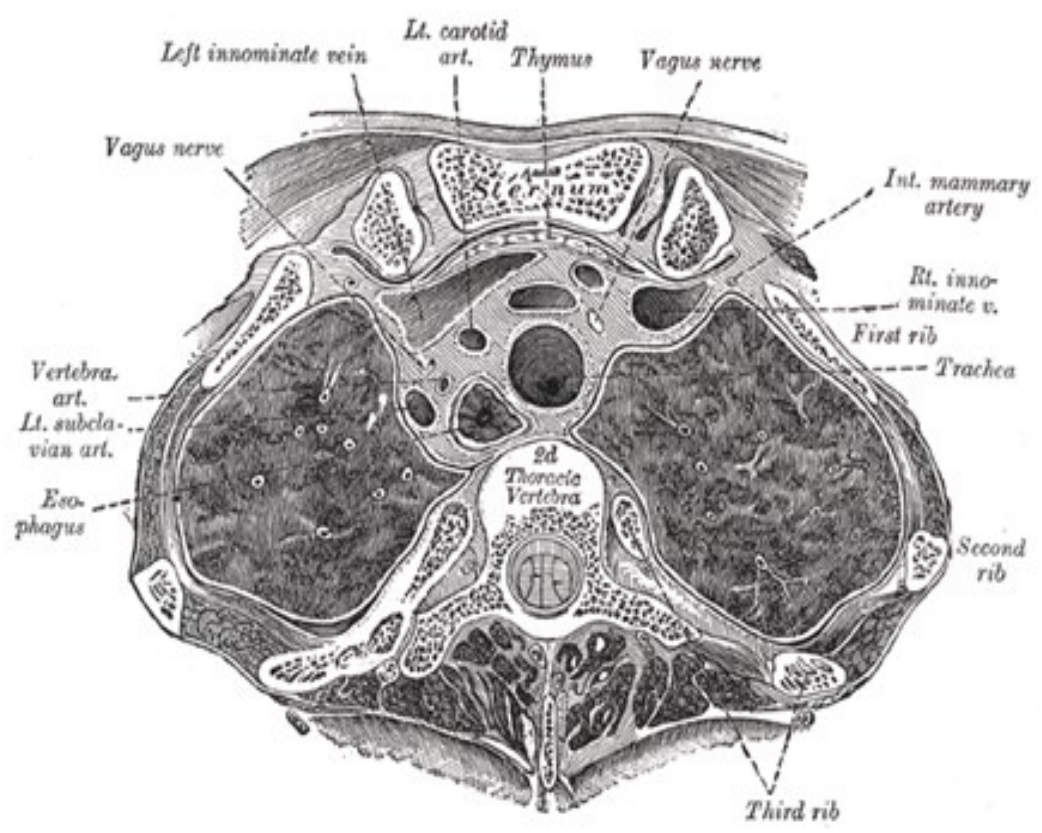

Gambar 1. Potongan melintang melalui batas atas vertebra thoraks dua

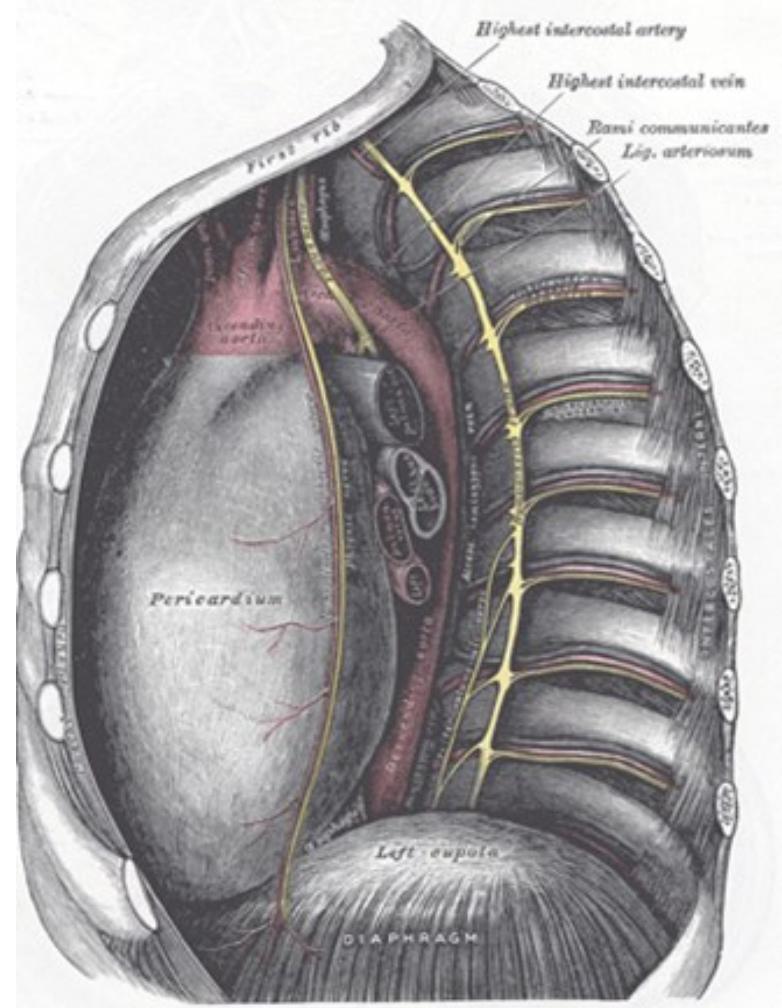

Gambar 2. Mediastinum medial dan posterior 


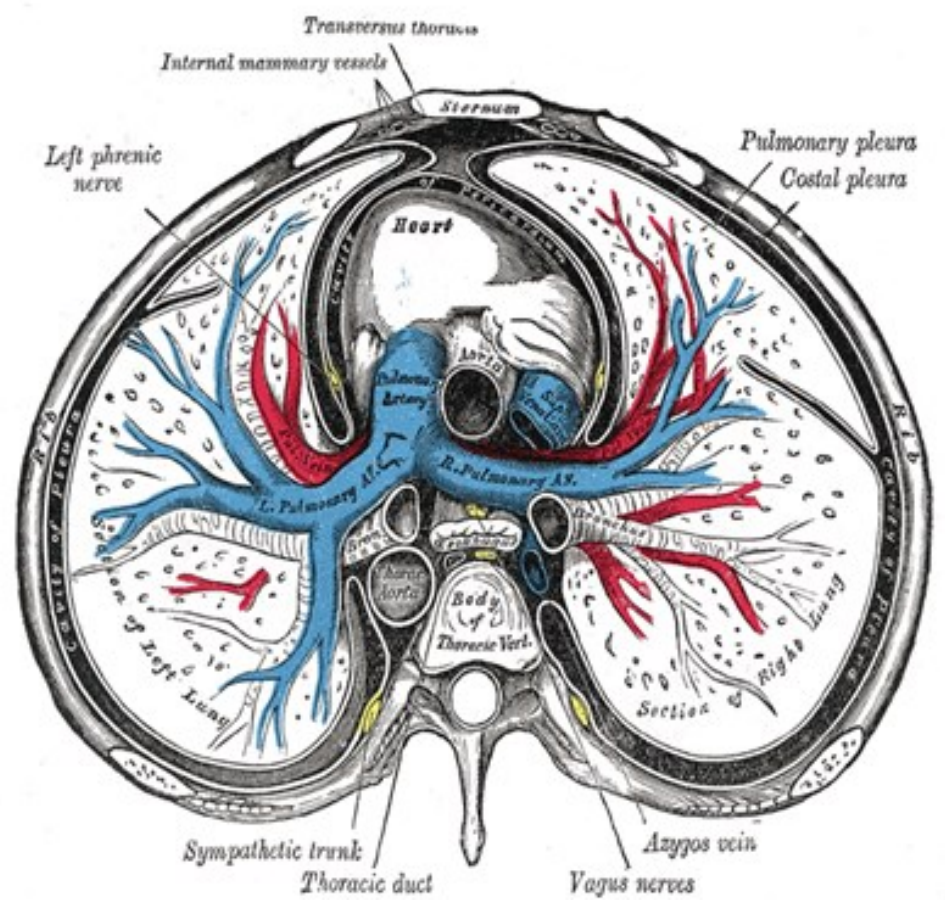

Gambar 3. Isi medastinum medial dan posterior

Tabel 1. Tumor gambaran mediastinum

Table I Conditions presenting as a mediastinal mass

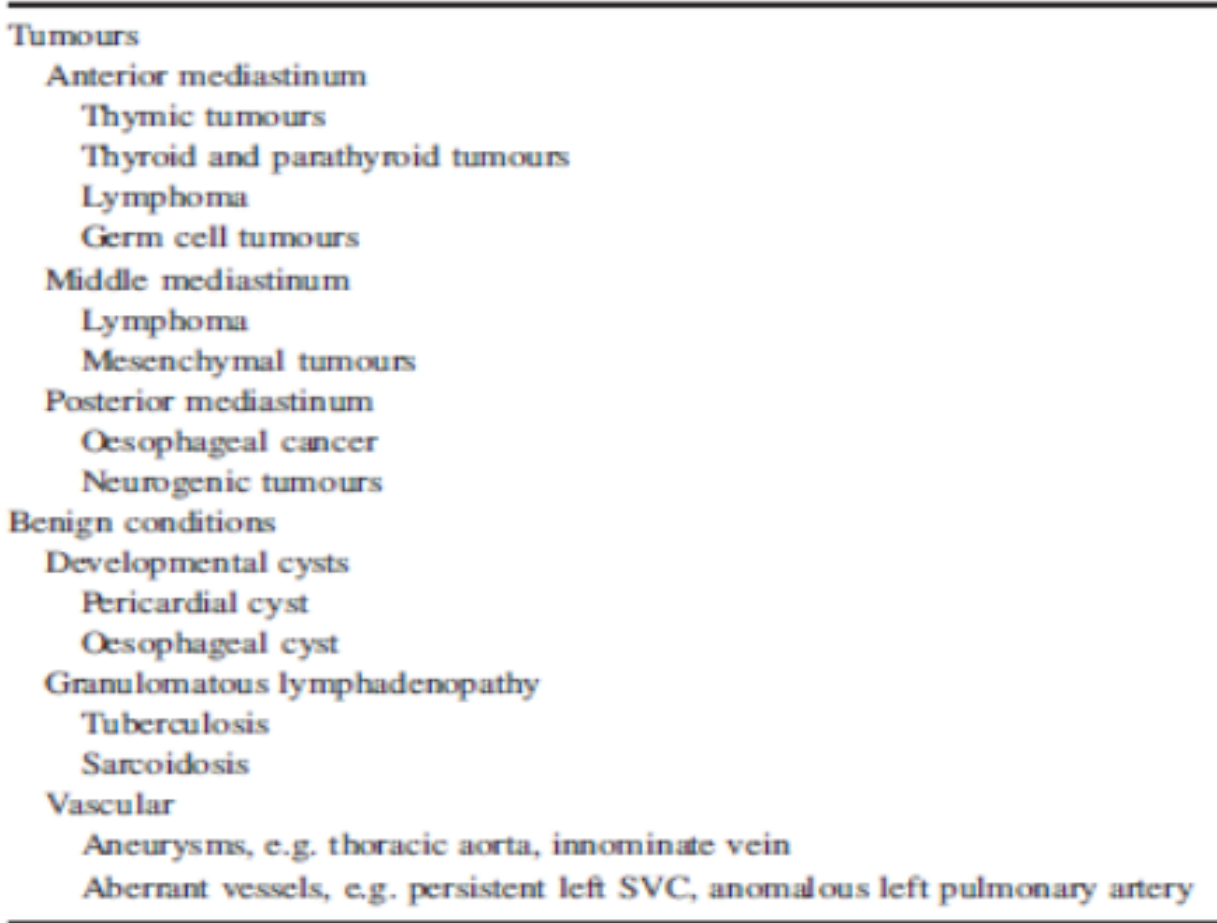




\section{MEDIASTINOSKOPI}

Mayoritas mediastinoskopi dilakukan melalui servikal, memasuki mediastinum melalui sayatan 3-cm pada takik suprasternal. Sebuah diseksi dibuat di antara vena innominata kiri dan sternum yang dibuat di lapisan fasia. Kemudian mediastinoscope tersebut dimasukkan lewat anterior ke lengkungan aorta. Pertemuan anterior yang jarang dilakukan adalah melalui ruang interkostalis kedua, perbatasan lateral dari sternum; teknik ini sering digunakan untuk pemutaran mediastinum yang lebih rendah. ${ }^{1,6}$

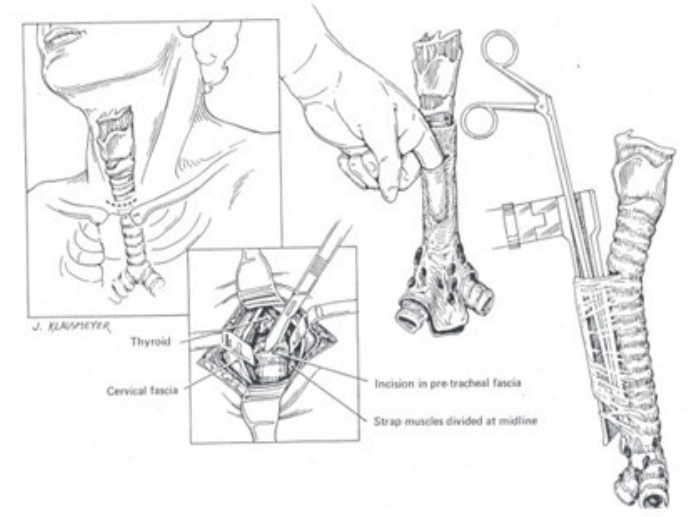

Gambar 4. Tindakan Mediastinoskopi

\section{Kontraindikasi}

Mediastinoskopi sebelumnya adalah kontraindikasi yang relatif kuat untuk dilakukan prosedur ulang karena jaringan parut menghilangkan letak dari diseksi. Sindrom Vena kava superior (SVC) meningkatkan risiko perdarahan dari vena yang terdistensi merupakan kontraindikasi relatif. Kontraindikasi relatif lain yaitu; deviasi trakea parah, penyakit serebrovaskular, gangguan tulang belakang leher yang parah, penyakit dengan ekstensi leher yang terbatas, radioterapi dada, dan adanya aneurisma aorta torakalis.

\section{PEMERIKSAAN}

Selain hematologi rutin, biokimia, dan EKG, pemeriksaan preoperative harus mencakup $\mathrm{X}$ foto thorax, dan $\mathrm{CT}$ scan bertujuan untuk mengevaluasi lokasi tumor, hubungannya dengan struktur yang berdampingan, dan tingkat kompresi trakea. Tes fungsi paru yang berguna dalam mendeteksi keparahan penyakit paru-paru dan efek massa mediastinum. arus- kurva volume yang harus diperoleh dalam posisi tegak dan terlentang untuk mengevaluasi gangguan fungsional dan memastikan adanya obstruksi. Kedua arus inspirasi dan ekspirasi biasanya berkurang bila terdapat massa intratoraks. Sebuah proporsional penurunan aliran ekspirasi maksimal meningkatkan kecurigaan dari munculnya tracheomalacia. Pemeriksaan tambahan (misalnya echocardiography dan stress tes) dapat diindikasikan dengan adanya gejala jantung. ${ }^{5}$ Namun, pada pasien yang sesuai, mediastinoskopi dapat dilakukan.

\section{MANAJEMEN ANESTESI}

Pertimbangan pra operasi

\section{Karsinoma bronkogenik}

Kebanyakan pasien dengan kanker paruparu adalah perokok sebagai comorbiditas yamg signifikan, termasuk hipertensi, penyakit arteri koroner, penyakit vaskular perifer, dan penyakit paru. ${ }^{3,4}$

\section{Massa mediastinum}

Pasien dengan massa mediastinum yang besar menyajikan sebuah tantangan yang sulit bagi dokter anestesi karena kompresi pada bagian-bagian vital penting yang berdekatan. Tingkat keparahan gejala yang dihasilkan tergantung pada ukuran dan lokasi dari 
massa, tingkat pertumbuhan, dan invasi struktur vital yang berdekatan. Namun, mayoritas pasien tidak bergejala dan ditemukan massa di dada pada pemeriksaan rutin $\mathrm{X}$ foto thorax. ${ }^{3,4}$

\section{Kompresi trakeobronkial}

Kompresi trakeobronkial mengarah ke persisten infeksi saluran pernapasan, wheezing pada satu sisi, atau stridor. Kejadian kesulitan dengan ventilasi dan henti jantung selama anestesi pada saat dilakukan prosedur diagnostik atau terapeutik dengan kasus massa mediastinum dengan baik dijelaskan., ${ }^{3}$ Namun, mendefinisikan kejadian yang sebenarnya dari komplikasi ini adalah sulit. Beberapa pusat telah melaporkan kejadian yang pada pasien pediatrik 7$20 \%$ selama anestesi dan $18 \%$ pada periode pasca operasi. insiden pada orang dewasa diyakini jauh lebih sedikit, ${ }^{5}$ kemungkinan karena saluran udara pada anak-anak yang sempit lebih rentan terhadap obstruksi.

Obstruksi trakeobronkial berpotensi dapat memperburuk dengan induksi dari anestesi umum dan ventilasi tekanan positif intermiten (IPPV). Penurunan fungsi dinding dada dan perpindahan cephalic diafragma menyebabkan hilangnya tekanan transmural distending gradien. Oleh karena itu, pemeliharaan ventilasi spontan sangat penting untuk menghindari pencetus obstruksi pada pasien ini. Awake Intubation atau induksi inhalasi dengan pemeliharaan spontan ventilasi dianjurkan tergantung pada derajat obstruksi dan gejala yang dihasilkan. Jika ada kesulitan dalam ventilasi karena obstruksi pada tingkat carina atau bronkus, sebuah bronkoskop harus dimasukkan dan ventilasi dipelihara dengan menghubungkan injector Sanders atau ventilator jet ke port sisi bronkoskop. Dengan adanya gejala obstruksi parah, stenting dapat dilakukan sebelum mediastinoskopi. ${ }^{3,4}$

\section{Sindroma SVC}

Kompresi SVC dengan pembesaran kelenjar getah bening atau massa mediastinum dapat mengakibatkan obstruksi aliran darah dari kepala,leher, dan ekstremitas atas, sehingga mengakibatkan SVC syndrome. ${ }^{6}$ Manifestasi klinis tergantung pada kecepatan pertumbuhan tumor dan pengembangan sirkulasi kolateral. Gangguan drainase vena menyebabkan lidah edema laring bengkak dan membuat intubasi berpotensi sulit. Pasien dengan pembengkakan orofacial yang luas, suara serak, dan distensi dari vena azygous pada CT scan meningkatkan risiko perdarahan dari trauma saat diintubasi. Kepala elevasi, steroid, dan diuretik dapat membantu dalam merunkan resiko sebelum operasi. ${ }^{6}$

\section{Efek sistemik}

Paru-paru atau tumor mediastinum menyebabkan gejala ekstra-toraks dengan penyebaran atau metastasis oleh sekresi hormon endokrin atau zat seperti, misalnya ACTH, ADH, PTH. ${ }^{5}$ Tabel 2 memberikan daftar sindrom paraneoplastik yang berkaitan dengan paru-paru kanker, yang memiliki implikasi anestesi. 
Table 2 Non-metastatic manifestations of mediastinal tumours

Endocrine

Hyperparathyroidism

Cushing's syndrome

Syndrome of inappropriate ADH secretion

Carcinoid syndrome

Neuromuscul ar

Myasthenia gravis

Eaton-Lambert syndrome

Peripheral neuropathy

Autonomic neuropathy

Hacmatological

Anaemia

Thrombocytopeni:

Thrombosis

Other

Nephrotic syndrome

Amyloidosis

Thymus tumor berhubungan dengan myasthenia gravis yang menyebabkan kelemahan dan kelelahan otot. Manifestasi klinis berkisar dari gejala ocular yang terisolasi hingga keterlibatan pernapasan otot. Pasien dengan myasthenia gravis sensitive terhadap pelumpuh otot non-depolarizing dan memiliki respon variable untuk agen depolarizing . Eaton-Lambert syndrome (sindrom myasthenic) miopati proksimal berhubungan dengan small cell carsinoma. Pengurangan asetilkolin yang dilepaskan dari saraf motorik terminal presinaptik pada pasien ini menyebabkan peningkatan sensitivitas untuk semua obat yang memblokir neuromuskuler . Berbeda dengan myasthenia gravis, dimana kelemahan otot meningkat dengan kegiatan fisik yang berat dan tidak dapat dibalik dengan terapi asetil kolinesterase inhibitor. ${ }^{4,6}$

\section{Pengelolaan Anestesi}

Sebuah short-acting benzodiazepine dapat diberikan untuk menurunkan kecemasan, namun, obat sedatif harus dihindari jika terdapat obstruksi trakea. ${ }^{4}$ Kanula intravena yang besar harus dimasukkan dan crossmatched darah harus tersedia karena potensi risiko perdarahan. Jika pasien asimtomatik, pre oksigenasi diikuti dengan induksi anestesi intravena dapat dilakukan. Dengan adanya obstruksi pernapasan, sebuah intubasi sadar di bawah anestesi lokal adalah teknik pilihan. Hal ini memungkinkan anestesi dan tim bedah melihat keseluruhan tingkat yang tepat dari obstruksi dan bila tabung endotrakeal dilewatkan distal obstruksi.

Dalam kasus obstruksi lebih distal (tingkat carinal), bronkoskop harus tersedia untuk frekuensi rendah ventilasi. Atau, induksi inhalasi dapat digunakan, diikuti oleh intubasi trakea dengan anestesi dalam. Pasien ditempatkan dalam posisi 20 derajat head-up untuk mengurangi kongesti vena, namun harus diingat bahwa ini Posisi ini meningkatkan kemungkinan emboli udara.

Sebuah agen anestesi intravena, anestesi inhalasi, atau keduanya, bersama dengan agen blok neuromuscular dan infus kontinu short-acting opioid akan memungkinkan sebuah tingkat yang memadai anestesi dan pemulihan pasca operasi cepat. Ventilasi kedua paru-paru melalui tabung endotrakeal tunggal lumen biasanya cukup. Sebuah tabung lebih disukai untuk meminimalkan risiko tabung terpuntir selama operasi. Endoskopi fiberoptik harus disiapkan sebelum ekstubasi untuk menyingkirkan tracheomalacia. ${ }^{5}$

Idealnya, relaksan otot harus dihindari pada pasien dengan sugestif sindrom klinis myaesthenic gravis. Jika menggunakan relaksan, dosis harus hatihati, dan dititrasi dengan respons yang 
diukur dengan pemantauan neuromuskular. Pasien diextubasi hanya bila setelah pemulihan refleks dan fungsi neuromuskuler baik; dalam jangka pendek ventilasi pasca operasi mungkin diperlukan.

Anestesi lokal lewat infiltrasi luka, blok saraf interkostal analgesia pasca operasi, Parasetamol Reguler dan NSAID (jika tidak kontraindikasi) dapat diberikan sebagai bagian dari multimodal analgesia. Pasca operasi, dada X-ray harus diambil pada semua pasien di ruang pemulihan untuk menyingkirkan kemungkinan pneumotoraks. Selanjutnya, pasien dapat dirawat di bangsal, dimana mereka harus diamati secara khusus untuk dyspnoea dan stridor, yang mungkin disebabkan oleh cedera pada laring berulang saraf atau hematoma paratrakeal. ${ }^{4,5,7}$

\section{MONITORING}

Pemantauan tekanan darah invasif, arteri line lebih disukai untuk deteksi dini refleks aritmia dan bila adanya kompresi pada vena besar selama tindakan mediastinoskopi, sebaiknya berlokasi dilengan kanan untuk deteksi kompresi brakiosefalika, yang berakibat pengurangan aliran darah ke arteri karotis kanan dan dapat menyebabkan iskemia dengan adanya sirkulasi kolateral yang tidak memadai. Atau, probe oksimeter pulsa harus ditempatkan pada tangan kanan. Pemantauan neuromuskular adalah wajib pada pasien dengan myasthenia gravis dan EatonLambert sindrom. Ventilator pengukur tekanan juga harus diperhatikan untuk mencatat setiap peningkatan tekanan saluran napas akut, yang menunjukkan adanya kompresi trakea atau bronkus oleh mediastinoscope tersebut. Penggunaan pressure controlled ventilasi membantu dalam deteksi dini kenaikan tekanan saluran udara. ${ }^{5,7}$

\section{KOMPLIKASI}

\section{Kerusakan pembuluh darah}

Insiden perdarahan utama setelah mediastinoskopi (Didefinisikan sebagai perdarahan yang persisten yang membutuhkan eksplorasi melalui sternotomy median atau torakotomi) adalah $0,4 \%, 8$ tetapi meningkat pada adanya kelainan pembuluh darah, peradangan mediastinum, dan SVC obstruksi. Pembuluh yang paling sering mengalami cedera adalah vena azigos, vena innominata, dan arteri pulmonalis.

Kontrol awal perdarahan dicoba dengan kompresi dan packing luka. Jika gagal untuk mengontrol perdarahan atau adanya ketidakstabilan hemodinamik persisten meskipun sudah dilakukan resusitasi volume maksimal, maka eksplorasi bedah diindikasikan. Vena innominata dan cedera arteri pulmonalis dapat diperbaiki melalui sternotomy garis tengah, sedangkan cedera vena azigos memerlukan torakotomi posterolateral kanan.

Prinsip-prinsip dasar manajemen adalah sama seperti yang dari setiap utama perdarahan, tetapi ada beberapa fitur unik untuk perdarahan mediastinum. Akses vena besar harus segera diamankan di tungkai bawah, karena perdarahan bisa dari gangguan pembuluh vena mengalir ke SVC. Beberapa penulis merekomendasikan akses vena pada tungkai rutin untuk semua pasien yang 
menjalani mediastinoskopi. Ini mungkin tidak dibenarkan mempertimbangkan kelangkaan perdarahan pada mediastinoskopi. ${ }^{9}$ Dalam kasus intubasi sulit atau lifethreatening dan resusitasi perdarahan, di mana dokter anestesi yang sibuk dalam resusitasi, intubasi pasien dengan lumen tabung tunggal dapat dilakukan. Selain itu, sebuah bronchial blocker dapat digunakan, namun penempatan yang akurat membutuhkan bronkoskop serat optik dan lebih banyak waktu diperlukan untuk menutup paruparu.

Cedera dari lengkung aorta dan supraarteri aorta jarang terjadi.Ini menyebabkan leher hematoma dan bila dilakukan reintubation membuat trakea sulit untuk diintubasi, meskipun pada intubasi awal mudah. Perdarahan ringan biasanya akibat dari luka pada pembuluh getah bening, hal ini respon dengan kompresi dan packing. ${ }^{9}$

\section{Kerusakan paru-paru}

Kejadian pneumotoraks setelah mediastinoskopi adalah 0,08-0,23\%. Thoracostomy tube harus dilakukan pada akhir operasi jika ada robekan pleura, dengan trauma jaringan paru-paru. Seorang pasien asimtomatik dengan pneumotoraks kecil (20\%) terdeteksi di pasca operasi hanya dapat diamati dengan $\mathrm{X}$ foto thorax. ${ }^{8}$

\section{Komplikasi lain}

Komplikasi berhubungan dengan mediastinoskopi termasuk (1) refleks bradikardi yang dimediasi vagus karena kompresi trakhea atau pembuluh darah besar, (2) perdarahan yang banyak , (3) iskemi cerebral karena kompresi arteri inominata (dideteksi dengan plethysmograf atau pulse oksimetri di tangan kanan), (4) pneumothoraks (biasanya terjadi postoperatif), (5) emboli udara (karena elevasi kepala $30^{\circ}$, resiko diperbesar selama ventilasi spontan), (6) kerusakan n. laryngeus reccuren, dan (7) cedera n. Phrenicus. ${ }^{8,9}$

Kemungkinan komplikasi lainnya termasuk stroke (brakiosefalikaarteri kompresi), cedera trakeobronkial, dan frenikus dan berulang cedera saraf laring (Tabel 3).

Table 3 Complications of mediastinoscopy

Major haemorrhage
Stroke
Air embolism
Pneumothorax
Reflex armythmias
Phrenic nerve paralysis
Recurrent laryngeal nerve palsy
Oesophageal tear
Tracheobronchial laceration
Thoradc duct injury
Minor bleeding

\section{RINGKASAN}

Mediastinoskopi semakin banyak digunakan di pusat-pusat kesehatan. Mediastinoskopi merupakan minimal invasif teknik untuk eksisi biopsi kanker paru-paru.

Mediastinoskopi menyediakan akses ke limfonodi mediastinal dan digunakan untuk diagnosis atau resektabilitas keganasan intrathorakal. CT preoperatif penting untuk evaluasi dan bila ada kompresi trakhea. Mediastinoskopi menggunakan anestesi umum. Akses vena dengan kateter intravena diameter besar (14 hingga 16 gauge) diharuskan karena resiko perdarahan berlebihan dan kesulitan pengendalian perdarahan. Dan diharapkan dengan tinjauan diatas maka dapat dipahami bagaimana pengelolaan anestesi pada pasien yang akan 
menjalani operasi mediastinoskopi.

\section{DAFTAR PUSTAKA}

1. Hammound ZT, Anderson RC, Meyers BF, et al. The current role omediastinoskopi in the evaluation of thoracic disease. $\mathrm{J}$ Thoracic Cardiovasc Surg 1999; 118: 894-9

2. Benumof JL. Anaesthesia for special elective diagnostic procedures. In: Anesthesia for Thoracic Surgery. Philadelphia: WB Saunders, 1995; 491-512

3. Hammer GB. Anaesthetic management for the child with mediastinal mass. Paed Anaes 2004; 14: 95-97

4. Narang S, Harte B, Body S. Anaesthesia for patients with a mediastinal mass. Anesthesiol Clin North America 2001; 19: 559-83

5. Bechard P, Letourneau L, Lacasse Y, et al. Perioperative cardiorespiratory complications in adults with mediastinal mass. Anesthesiology 2004; 100: 826-34

6. Jahangari M, Goldstraw P. The role of mediastinoskopi in superior vena caval obstruction. Ann Thorac Surg 1995; 59: 453-552

7. Cybulsky IJ, Bennett WF. Mediastinoskopi as a routine outpatient procedure. Ann Thorac Surg 1994; 58: 176-8
8. Park BJ, Flores R, Downey RJ, et al. Management of major haemorrhage during mediastinoskopi. J Thorac Cardiovasc Surg 2003; 126: 726-31

9. Lohser J, Donington JS, Mitchell JD, et al. Anaesthetic management of major haemorrhage during mediastinoskopi. J Cardiothorac Vasc Anesth 2005; 19: 678-83 